\title{
Pemanfaatan Gas Buang pada Waste Heat Recovery Power Generation untuk dikonversi menjadi Energi Terbarukan di Indarung V, PT. Semen Padang, Indonesia
}

\author{
Nasrul Harun ${ }^{1 *}$, Valdi Rizki Yandri ${ }^{2}$ \\ ${ }^{12}$ Jurusan Teknik Elektro, Politeknik Negeri Padang \\ Jurusan Teknik Elektro Politeknik Negeri Padang, Jl. Limau Manih Padang, 25164, Indonesia \\ *Corresponding Author, email: nasrul.harun1959@gmail.com
}

\begin{abstract}
Abstrak - Proses pembakaran batu bara yang membutuhkan temperatur tinggi akan menghasilkan energi kalor terbuang yang dapat digunakan sebagai penggerak generator sehingga menghasilkan energi listrik. Oleh karena itu, P.T. Semen Padang berhasil mendapatkan pendanaan dari pemerintah Jepang, Organisasi Pengembangan Teknologi Energi Baru Terbarukan (NEDO) untuk membangun Pembangkit Listrik Tenaga Limbah Kalor atau Waste Heat Recovery Power Generator (WHRPG) di area produksi Semen Padang, Indarung V. Pemanfaatan energi panas tidak dapat dioperasikan secara manual, sehingga sistem kendali diperlukan untuk mengendalikan kinerja WHPRG ini. Operasional WHPRG dapat menghaslikan daya listrik 196,15 MW sehingga dapat mengurangi daya listrik yang harus disuplai oleh PT. PLN (Persero). Selain itu, pengeluaran PT. Semen Padang pun dapat dihemat sejumlah Rp. 33 milyar per tahun dan emisi CO2 dapat dikurangi sejumlah 33.000 ton per tahun.
\end{abstract}

Kata kunci: Pembangkit Listrik Tenaga Limbah Kalor (WHRPG), daya listrik, energi baru terbarukan

\begin{abstract}
The coal combustion processes which require high temperature will produce waste heat energy. The energy can be used as generator propulsion to produce electrical energy. Thus, Semen Padang Corporation has successfully got funding from the Japan government, New Energy Technology Development Organization (NEDO) to build the installation Waste Heat Recovery Power Generation (WHRPG) located in the production area of Semen Padang Corporation, Indarung $V$. Furthermore, heat energy process can not be operated manually, so control system is needed to control this WHPRG performance. The operational of WHPRG can produce electricity power $196.15 \mathrm{MW}$ as to reduce the electric power that must be supplied by Indonesian Electricity Corporation. Besides that, the outcome of Semen Padang Corporation can be saved 33 billion Rupiah per year and CO2 emission can be declined 33,000 tons per year.
\end{abstract}

Keywords: Waste Heat Recovery Power Generation (WHRPG), electrical power, renewable energy

(C) 2020 Elektron Jurnal Ilmiah

\section{I.PENDAHULUAN}

Dalam beberapa tahun terakhir, pemanfaatan sumber energi kalor seperti panas bumi, gas sisa turbin dan limbah kalor dari industri menarik perhatian berbagai kalangan. Hal ini bertujuan untuk mengurangi konsumsi bahan bakar fosil dan mengurangi limbah dari industri [1]-[3]. Energi kalor merupakan kebutuhan yang tidak bisa dihindari pada berbagai industri. Namun demikian, limbah kalor yang berlebihan tidak dapat dihindari dan tidak dapat digunakan kembali di industry [4]-[6].

Limbah kalor dari pembangkit listrik termal berasal dari kalor pada bagian input, dan dapat mencapai 55\% dari total kalor dari bahan bakar yang digunakan. Pemanfaatan kembali limbah kalor merupakan hal penting tetapi masih membutuhkan penelitian dan pengembangan. Pemanfaatan limbah kalor dapat mengurangi polusi termal dan mendukung konservasi energi [7], [8]. Generator termoelektrik dapat memanfaatkan energi termal untuk dikonversi menjadi energi listrik berdasarkan pada ketiga efek termoelektrik, yaitu efek Seebeck, efek Peltier dan efek
Thomson [9], [10]. Efek Seebeck terjadi saat potensial listrik yang dihasilkan pada rangkaian terbuka yang terbentuk oleh dua konduktor berbeda saat sambungan kedua konduktor ini dipertahankan pada temperatur yang berbeda. Efek Peltier menyatakan bahwa kalor dapat diserap atau dibebaskan di sambungan dua konduktor berbeda saat adanya aliran arus listrik [11]. Efisiensi konversi modul termoelektrik yang masih rendah $(<5 \%)$ menjadi faktor utama penyebab aplikasinya masih terbatas dalam pembangkit tenaga listrik dan juga untuk situasi khusus dimana keandalan merupakan pertimbangan utama [12].

Oleh karena ditingkatkannya perlindungan lingkungan, aplikasi teknologi thermoelectric dipelajari secara ekstensif. Generator termoelektrik (TEG) dapat mengkonversi energi termoelektrik dengan cara yang sederhana dan dapat diandalkan. Selain itu, modul TEG memiliki kelebihan ramah lingkungan sehingga penggunaan TEG untuk mengolah limbah kalor telah dibahas secara komprehensif di berbagai industri. Selama 30 tahun terakhir, penerapan teknologi termoelektrik bertambah untuk meningkatkan efisiensi pengolahan kalor limbah, dengan menggunakan 
berbagai sumber kalor seperti energi panas bumi, pembangkit listrik, mobil dan proses penghasil kalor lainnya di industry [13], [14].

Generator termoelektrik juga dapat meningkatkan kemampuan ICE untuk mengubah bahan bakar menjadi daya yang bermanfaat. Dengan mengubah limbah kalor menjadi listrik, kinerja mesin, efisiensi, keandalan, dan fleksibilitas desain dapat ditingkatkan secara signifikan [15], [16]. Proses pembakaran batubara membutuhkan suhu tinggi dan akan menghasilkan limbah kalor yang dapat dimanfaatkan sebagai sumber energi untuk pembangkit tenaga listrik. PT. Semen Padang berhasil mendapatkan pendanaan dari pemerintah Jepang, Organisasi Pengembangan Teknologi Energi Baru Terbarukan (NEDO), untuk mengembangkan Pembangkit Listrik Tenaga Limbah Kalor (WHRPG) di daerah produksi Semen Padang.

\section{TINJAUAN PUSTAKA}

A. Deskripsi Proses Produksi Semen

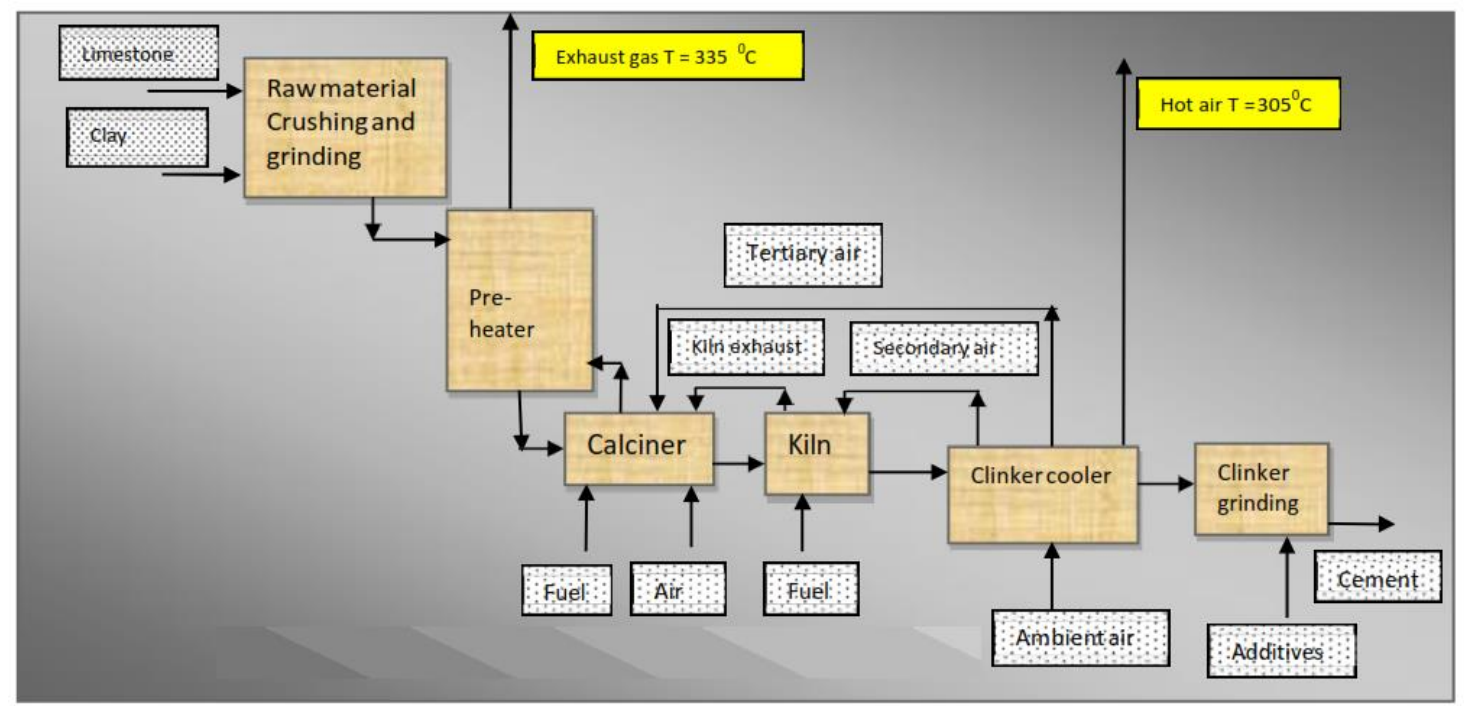

Gambar 1. Proses Manufaktur Semen [17]

B. Pemanfaatan Gas Pembuangan dari Proses Manufaktur Semen

Berdasarkan proses manufaktur semen tersebut, terdapat gas pembuangan pada temperatur yang cukup tinggi yang memiliki energi kalor sehingga dapat dimanfaatkan untuk dikonversi menjadi energi listrik. WHRPG dapat dimanfaatkan untuk proses konversi ini dan memberikan banyak manfaat bagi PT. Semen Padang dalam bentuk penghematan energi, pengurangan emisi $\mathrm{CO}_{2}$, sehingga membuat industri ini ramah lingkungan.

Pemanfaatan WHRPG ini juga bertujuan untuk menghemat energi dan meminimalkan emisi $\mathrm{CO}_{2}$ melalui Clean Development Mechanism (CDM) sebagai implementasi Protokol Kyoto. Terdapat ruang lingkup yang besar dalam memulihkan limbah kalor dari berbagai industri untuk menghasilkan listrik melalui proses pada heat recovery steam generator (HRSG). HRSG juga dapat digunakan dalam turbin gas
Semen diproduksi dengan mencampurkan alumina yang berkapur dengan silika besi oksida, kemudian membakarnya pada temperatur tertentu dan menggilingnya. Untuk memproduksi 1 ton semen Portland, dibutuhkan sekitar 1,5 - 1,7 ton bahan baku, 0,13 ton batu bara. Proses produksi semen memiliki tiga tahapan utama. Tahap pertama adalah tahap pencampuran dan penghancuran untuk mencampur jumlah tertentu dari tanah liat dan batu kapur sehingga menjadi bentuk bubuk. Tahap kedua adalah proses pyro yang membutuhkan lebih dari $90 \%$ total energi. Tahap ini termasuk preheater, calciner, kiln dan pendinginan.Clinker adalah produk utama dari tahap ini yang kemudian dikirim ke tahap penggilingan dan penghancuran akhir di pabrik semen. Selama tahap ketiga, clinker dihancurkan dan digiling menjadi butiran kecil dalam bentuk bubuk, dicampur dengan bahan aditif dan kemudian dilanjutkan ke tahap pengemasan [17]. 
dimana $V$ adalah volume tangki air, $r$ adalah is jari-jari tangki air dan $h$ adalah tinggi tangki air.

B. Perhitungan akselerasi aliran air Akselerasi aliran air dihitung dengan menggunakan persamaan berikut :

$$
a=\frac{v}{t}
$$

dimana $a$ adalah akselerasi aliran air, $v$ adalah kecepatan aliran air dan $t$ adalah waktu untuk pengisian tangki demineralizer.

\section{Perhitungan massa air}

Massa air dapat dihitung dengan menggunakan persamaan berikut :

$$
m=\rho \times V
$$

dimana $m$ adalah massa air, $\rho$ adalah massa jenis air dan $V$ adalah volum tangki air.

D. Perhitungan gaya dari aliran air

Gaya akibat aliran air dapat dihitung dengan menggunakan persamaan berikut :

$$
F=m \times a
$$

dimana $F$ adalah gaya dari air, $m$ adalah massa air dan $a$ adalah akselerasi aliran air.

E. Perhitungan usaha dari aliran air Usaha dari aliran air dapat dihitung dengan menggunakan persamaan berikut :

$$
W=F \times d
$$

dimana $W$ adalah usaha dari air, $F$ adalah gaya dari air dan $d$ adalah jarak dari tangki air ke boiler.

F. Perhitungan daya listrik

Daya listrik dapat dihitung dengan menggunakan persamaan berikut :

$$
P=\frac{W}{t}
$$

dimana $P$ adalah daya listrik, $W$ adalah usaha dari aliran air dan $t$ adalah waktu untuk pengisian tangki air.

\section{IV.HASIL DAN PEMBAHASAN}

Berdasarkan data tangki air dan peralatan lainnya, maka dapat dihitung daya listrik yang dapat dihasilkan WHRPG sebagai berikut :

Jari-jari tangki air $=1,75 \mathrm{~m}$

Tinggi tangki air $=4 \mathrm{~m}$

Massa jenis air $=1.000 \mathrm{~kg} / \mathrm{m}^{3}$

Waktu untuk pengisian tangki demineralizer $=1,5$ jam Jarak dari tangki air ke boiler $=255 \mathrm{~m}$

Diameter pipa $=30 \mathrm{~cm}$

Berdasarkan persamaan (1) :

Volum tangki air $=38,46504 \mathrm{~m}^{3}$

Kecepatan aliran air $=30 \mathrm{~km} / \mathrm{jam}$
Berdasarkan persamaan (2) :

akselerasi $=\frac{30 \mathrm{~km} / \mathrm{jam}}{1,5 \mathrm{jam}}$

akselerasi $=20,000 \mathrm{~m} / \mathrm{jam}^{2}$

akselerasi $=5,555.556 \mathrm{~m} / \mathrm{s}^{2}$

Berdasarkan persamaan (3) :

Massa air $=1,000 \mathrm{~kg} / \mathrm{m}^{3}$ x $38.46504 \mathrm{~m}^{3}$

Massa air $=38.465,04 \mathrm{~kg}$

Berdasarkan persamaan (4) :

Gaya $=38.465,04 \mathrm{~kg} \mathrm{x} \mathrm{20,000} \mathrm{m/jam}{ }^{2}$

Gaya $=769.210 .800 \mathrm{~N}$

Berdasarkan persamaan (5) :

Usaha $=769.210 .800 \mathrm{~N}$ x $255 \mathrm{~m}$

Usaha $=196.148 .754 \mathrm{~kJ}$

Berdasarkan persamaan (6) :

Daya $=\frac{\text { Usaha }}{\text { waktu }}$

Daya $=\frac{196.148 .754 k J}{1 \text { jam }}$

Power $=196,15 M W$

Artinya, daya listrik yang dapat disuplai dari pemanfaatan WHRPG adalah 196,15 MW. Pemanfaatan WHPRG di PT. Semen Padang dapat mengurangi pengeluaran sejumlah Rp. 33 milyar per tahun dan juga mengurangi konsumsi listrik dari PT. PLN. Penghematan ini juga dapat mereduksi emisi $\mathrm{CO}_{2}$ sejumlah 33.000 ton per tahun.

Jika sistem pembangkit listrik di grup PT. Semen Padang sudah menerapkan WHRPG, maka energi kalor yang sebelumnya terbuang ke udara bebas dapat dimanfaatkan untuk meningkatkan efisiensi proses produksi dan laba perusahaan. Dengan demikian, pemerintah Indonesia yang memiliki 51\% saham di PT. Semen Padang, akan mendapatkan dividen lebih besar. Pada tahun 2013, Pemerintah Indonesia memperoleh dividen lebih dari Rp. 1,2 triliun.

\section{KESIMPULAN}

Pemanfaatan WHRPG dapat mensuplai daya listrik sebesar 196,15 MW untuk kebutuhan PT. Semen Padang. Dengan demikian daya listrik dari WHRPG ini dapat digunakan untuk proses lain, terutama proses produksi. Daya listrik yang dihasilkan melalui pemanfaatan WHRPG juga dapat mengurangi konsumsi energi listrik yang harus disuplai PT. PLN (Persero) sehingga sejumlah daya listrik ini dapat disalurkan untuk kebutuhan pelanggan listrik lainnya. 


\section{UCAPAN TERIMA KASIH (ACKNOWLEDGEMENT)}

Penulis mengucapkan terima kasih kepada pimpinan Politeknik Negeri Padang yang telah membantu untuk menjalin kerjasama dengan PT. Semen Padang sehingga dapat mempermudah dalam pengumpulan data.

\section{REFERENSI}

[1] G. Györke, A. Groniewsky, and A. R. Imre, "A Simple Method of Finding New Dry and Isentropic Working Fluids for Organic Rankine Cycle," MPDI Energies, vol 12 , no. 480 , pp. $1-11,2019$.

[2] W. Xu, S. Deng, Y. Zhang, D. Zhao, and L. Zhao, "How to give a full play to the advantages of zeotropic working fluids in organic Rankine cycle (ORC)," Energy Procedia, vol. 158, pp. 1591-1597, 2019.

[3] H. Yu, D. Kim, and T. Gundersen, "A Study of Working Fluids for Organic Rankine Cycles (ORCs) Operating Across and Below Ambient Temperature to Utilize Liquefied Natural Gas (LNG) Cold Energy,” Energy, vol. 1, pp. 1-10, 2018.

[4] P. Li, Z. Han, X. Jia, Z. Mei, X. Han, and Z. Wang, "Comparative analysis of an organic Rankine cycle with different turbine efficiency models based on multiobjective optimization," Energy Convers. Manag., vol. 185 , pp. 130-142, 2019.

[5] H. Yanga, C. Xua, B. Yanga, X. Yua, Y. Zhangb, and Y. $\mathrm{Mu}$, "Performance analysis of an Organic Rankine Cycle system using evaporative condenser for sewage heat recovery in the petrochemical industry," Energy Convers. Manag., vol. 205, p. 112402, 2020.

Lili Wei, Z. Ma, X. Gong, and X. Guo, "Experimental investigation and performance analysis of an Organic Rankine Cycle for low-temperature heat to electricity generation," Int. J. Low-Carbon Technol., vol. 1, pp. 1-8, 2019 .

[7] A. G. Mohammed, M. Mosleh, W. M. El-Maghlany, and N. R. Ammar, "Performance analysis of supercritical ORC utilizing marine diesel engine waste heat recovery," Alexandria Eng. J., vol. 59, pp. 893-904, 2020.

[8] Deepak Tiwari, A. F. Sherwani, M. Muqeem, and A Goyal, "Parametric optimization of organic Rankine cycle using TOPSIS integrated with entropy weight method," Energy Sources, vol. Part A, pp. 1-18, 2019.

[9] X. Guo et al., "Energetic and exergetic analyses of a combined system consisting of a high-temperature polymer electrolyte membrane fuel cell and a thermoelectric generator with Thomson effect," Int. J. Hydrogen Energy, vol. 44, pp. 16918-16932, 2019.

[10] M. Kalteh and H. A. Garmejani, "Investigating the influence of Thomson effect on the performance of a thermoelectric generator in a waste heat recovery system," Int. J. Green Energy, vol. 1, pp. 1-13, 2019.

[11] S. Lan, A. Smith, R. Stobart, and R. Chen, "Feasibility study on a vehicular thermoelectric generator for both waste heat recovery and engine oil warm-up," Appl. Energy, vol. 242, pp. 273-284, 2019.

[12] D. Luo, R. Wang, W. Yu, and W. Zhou, "Parametric study of a thermoelectric module used for both power generation and cooling," Renew. Energy, vol. 154, pp. 542-552, 2020.

[13] S. P. Burugupallya, L. Weiss, and C. Depcik, "The effect of working fluid properties on the performance of a miniature free piston expander for waste heat harvesting," Appl. Therm. Eng., vol. 151, pp. 431-438, 2019.

[14] Z. Y. Xu, R. Z. Wang, and C. Yang, "Perspectives for lowtemperature waste heat recovery," Energy, vol. 176, pp. 1037-1043, 2019.

[15] N. Jaziri, A. Boughamoura, J. Müller, F. Tounsi, B. Mezghani, and A. Kouki, "TCs Connectivities Effect Investigation in the LTCC-based Thermoelectric Generator for Automotive Waste Heat Recovery," in IEEE International Conference on Design \& Test of Integrated Micro \& Nano-Systems, 2019, pp. 1-5.

[16] R. Rodriguez, M. Preindl, J. S. Cotton, and A. Emadi, "Review and Trends of Thermoelectric Generator Heat Recovery in Automotive Applications," IEEE Trans. Veh. Technol., vol. 1, pp. 1-14, 2019.

[17] M. Sathiyamoorthy and M. Biglari, "A case study: the waste heat recovery and utilization for power generation in a cement plant (phase-1)," Adv. Res. IT Eng., vol. 5, pp. 126, 2016.

[18] H. Gao et al., "Numerical study of heat transfer characteristics of semi-coke and steam in waste heat recovery steam generator for hydrogen production," Int. J. Hydrogen Energy, vol. 44, pp. 25160-25168, 2019. 